Covered in: Web of Sciences (WOS); EBSCO; ERIH+; Google Scholar; Index Copernicus; Ideas RePeC; Econpapers; Socionet; CEEOL; Ulrich ProQuest; Cabell, Journalseek; Scipio; Philpapers; SHERPA/RoMEO repositories; KVK; WorldCat; CrossRef; CrossCheck

\section{Ontological Basis of the Education \\ Phenomenon as a Preformer of Its Social and Existential Realities}

\author{
Alexander KARPOV ${ }^{1}$ \\ ${ }^{1}$ Bauman Moscow State Technical \\ University, Moscow, Russia, \\ a.o.karpov@gmail.com
}

Abstract: This study is aimed at explication the structure of ontological basis of the education phenomenon from the standpoint of the truth of its being and reality. The methodology of the study is based on separation of existence and being concepts in the education phenomenon and identification of predetermining relationships between them. The methodology and results of the work are the author's own contribution. As a result of the study, the ontological basis of the education phenomenon is presented as a set of the following components: (1) ontological principles educational universals and paradigmatic relations; (2) ontological essence. Their relationship with the truth of being of the education phenomenon is shown. The role of the ontological essence in the formation of social and existential realities of education is revealed. The content of structural, procedural, psychic and distributive universals is defined as a pre-image of the general in teaching and learning diversity. Forms, ways, functions and generalization of the being of the education phenomenon, which determine the particular in its reality, are taken as paradigmatic relationships. In connection with preformativity of the education phenomenon, a nonKuhnian definition of the paradigm is developed, and the role of paradigms of education advancement is identified. Examples are given showing the significance of components of the ontological basis in the formation of the education reality. The conclusion is drawn that the ontological basis predetermines the presence of the social and existential necessary in education reality, and its deficit makes problematic the ability of education to be itself.

Keywords: Education; ontology; society; trutb; reality.

How to cite: Karpov, A. (2019). Ontological Basis of the Education Phenomenon as a Preformer of Its Social and Existential Realities. Postmodern Openings, 10(1), 220235. https://doi.org/10.18662/po/64 



\section{Introduction}

Education plays the role of a key instrument in social transformations that ensure development of a modern community and formation of a knowledge society. At the same time, sciences of education suffer from a deep crisis caused by inability to create culturally authentic models of modern education and its development. This crisis is a consequence of positivistic attitudes toward reflection, researches and implementation of education, which is determined by practical values that destroy its fundamental bases. As a result, for the most part the modern educational theory is based on analytical-empirical research schemes (Pinar, 2012), and a philosophical essay becomes a main form of a curriculum inquiry (Schubert, 1991).

The era of "social effectiveness" in education excluded the ontological view of it (Aoki, 2004). Meanwhile, a practical theory can offer only speculative and preliminary ideas of education. At the heart of fundamental theoretical concepts of the education phenomenon there is always one or another ontology, regardless of whether it is perceived by a researcher or not (Schatzki, 2003); and existential-ontological relations between a teacher and a learner, being "intangible", are no less real than the world of things around them (Magrini, 2012). In other words, the educational theory, in order to be authentic, should be able to connect different levels of reality, including "ephemeral" (Poli, 2010).

According to M. Heidegger (1998), "education" and "truth", comprehended from the Greek understanding as paideia $(\pi \alpha \mathrm{l} \delta \varepsilon i \alpha)$ and alethaea $(\alpha \lambda \dot{\eta} \theta \varepsilon \varepsilon \alpha)$, come together into an essential unity. He writes about necessary radical rethinking of education (Heidegger, 1977a). I. Thomson (2004), referring to this thought of Heidegger, uses the "ontologization of education" notion. Education should be ontologized through contexts of human interweaving with the world (Dall'Alba, 2009). Of course, the instrumental action of education, when it carries knowledge, skills, competences, plays an essential role in the modern society. At the same time, the instrumental-epistemological view of education closes the problem how it transforms a youngster into a person.

Experts associate the crisis of sciences of education with an impoverished ontological status of modern "standardized" education (Magrini, 2014). They point to a cultural backwardness of education from present-day cognitive conditions, because scientific thinking today uses the conceptual dictionary of Bohr, Heisenberg and Prigozhin, while curricula 
find themselves closer to the ontological system of Descartes, Newton and Laplace (Doll, 1993). Hidden or weakly elaborated are approaches to supporting structures and relationships laid down in the foundation of education and to be used in creation its theoretical models that determine learning and transformation processes of the education system. Meanwhile, the ontological core of the education phenomenon predetermines the essence in its reality - the education phenomenon without this core can't be itself or, in other words, it preforms its existence.

In this work, the "existence" notion means the world of reality in presence (staying of what is) in the past, nowadays or in the future in its time duration, and the term "being" is the world of not-having-existence as the timeless reality containing a place of being for a certain what is (existing things and phenomena) that gives it the existence. Unlike the existence, the being has no geography and history. The truth of being of a certain social what is - the phenomena of education, politics, power, etc., is manifested itself in arranging the place of its being. It determines fundamental bases from which the social what is should originate in its existence, so as not to lose its essence. To reconcile these notions, we will treat the existence as a boundary form of the being located above it and directly adjacent to it, just as a "punctured" 1 adjoins a half-open segment $[0,1)$.

The difficulty and social relevance of the problem of the ontological bases of education requires rethinking to acquire better knowledge. This text presents one of outlines of its solution.

\section{Problem Statement}

What is the truth of the education phenomenon in the "here and now" reality? It is in its compliance with an ideal project of education the society deems it should be and become. It is in its capacities for cognitive penetration into the world promoting personal fulfillment. It is in keeping its essence, which is, in part, culturally and historically pre-determined and, due to today's complexity of the society, is very versatile. From this point of view, the question is about the true existence of education in presence with account of conditions, possibilities and requirements of cultural-historical and socio-economic development.

But, at the same time, education as a phenomenon has not only existence but also being which is self-sufficient and independent, timeless and ahistorical. Education as a phenomenon in its arrangement rests on deep and primordial - on the ontological basis, which is its localization and bearer in being or, in other words, the place of its being. Consequently, the 
variety of true forms of education in presence is generated by a maternal arche, located in the being and authorizing their existence by the truth of its being.

The task of the work is to study the ontological core of the education phenomenon in connection with its determining influence on ability of education to be itself.

\section{Research Questions / Aims of the research}

1) What is the structure of the ontologically pre-given part of the education phenomenon that underpins its potential realizations?

2) How does this pre-given part determine social and existential realities of education?

The aim of the research is explication the structure of the ontological basis of the education phenomenon from the standpoint of the truth of its being and reality.

\section{Research Methods}

The methodological basis of the study is an interdisciplinary approach developed by the author to the study of education as a sociocultural phenomenon (Karpov, 2015). Within the framework of this approach, the phenomenon is structured into a system of essential spaces: (1) the spaces of reality - the universum and generative-constitutive and (2) the space of being - the ontogenic. The universum space defines the context of the phenomenon - the socio-cultural and anthroposocial realities of education. In the generative-constitutive space, the educational function of the phenomenon is studied - learning, upbringing, and institutionalization. In the ontogenic space, the fundamental bases of the education phenomenon are analyzed (Karpov, 2018).

To investigate the dependencies between the ontogenic space and the reality of education, methods of structural-functional analysis, philosophical ontology, sociology and cognitive psychology are used. In the ontological development of the problem, a special role is played by the nonKuhn's (performative) theory of social paradigms, developed by the author (Karpov, 2013). The relations between the ontogenous space and the reality are studied by an example of Russian education.

The key methodological principle of the study is separation of existence and being concepts of a social phenomenon. This approach is associated with a special type of what is involved in the study - a man and his/her collectives. A man is involved into being not only as a visionary, a 
representer of what is or a doer of things. Man creates what is of social nature, which acquires fundamental bases in being, thereby becoming, in many ways, independent from its creator, something established from itself. The social what is is a place for unfolding of a human nature and comparison of a socially produced thing with the truth of its being.

\section{Findings and discussions}

\subsection{Ontological basis of the education phenomenon}

Into the ontological basis of the education phenomenon I include ontological principles - primary educational constituents (generating elements) and fundamental paradigmatic relations, as well as the ontological essence, which are the very core of the ultimate reality of the phenomenon. The ontological principles shape the place of being of the education phenomenon, from which it culturally and historically sprouts up. The ontological essence makes sprouting possible.

Let us briefly analyze these concepts.

Primary educational constituents are a pre-image of universal education in its teaching and learning diversity; fundamental relations of the paradigmatic type are the place of peculiar in it, i.e. the former determine ontologically static in the being of the education phenomenon, and the latter - ontologically dynamic. Ontological principles create a duality in the nature of the education phenomenon: the universal makes it what it should be, characterizes the necessary and unchangeable in it; the peculiar specifies spaces of changes that make up the diversity of education.

In-depth dichotomy of "similar - different", found in the ontologically ultimate of the education phenomenon gives an evidence of the structural complexity of the truth of education. The location of its manifestation is a gap between the timeless ontological essence of the education phenomenon and its socially contextual incarnations. The gaps occur if doctrinal enforcement deforms the universal of educational essence or eliminates the link between its present and indispensably inherited and oriented to the future.

The essence of education has an ontological dimension. It takes its roots in the being by its core - the ontological essence laying in the ontological basis of education that holds together the ontological principles to form the pre-phenomenon integrity. And this integrity produces the phenomenon of education from the being into existence, establishing it as an ideal what is, giving rise to social and historical replicas within the contextual reality. When deconstructing the ontological principles, education 
loses its essence, becomes a phenomenon of "education beyond the truth", which has nothing in common with education.

Consequently, the education phenomenon in the "here and now" reality, i.e. in its existence, can be subjected to questioning about the truth of its being and thereby to checking for compliance with this truth. The essence of the instrumental part of the question is a comparison of the ideal what is of the education phenomenon with its current what is and clarification a deficiency in the ideal in the existence of education. The absence of deficiency in the ideal is an ontological criterion of the truth of the education phenomenon in presence. Deficiency in the ideal is not only in a shortage of the present, but also in breaks with the past, that destroy the placenta of cultural growth, as well as in the deficit of the future that prevents entry into it.

\subsection{Ontological essence of education in relation to the truth}

The ontological view on the education phenomenon makes it possible to clarify the problem with its multi-sided essence. Different sources take the essence of education as acquisition of knowledge and skills, formation of an all-round personality, transfer of social and historical experience, development of feelings and culture of thinking, individual and social capitalization of knowledge, formation of a picture of the world and inheritance of cultural traditions; civic education and assimilation of values, etc. This polysemy is the result of different perspectives of education representation, which is interpreted as teaching and public outreach, institution and a system, a value and upbringing, diploma and qualification, knowledge storage and socialization. It points to a different understanding of the path of a person running through the phenomenon of "education".

Thus, within the multivalued identification of the essence of education, there is an ontological nucleus, which points to the human basis in its one or another disclosure. The ontological essence of education is cultivation of humanity, i.e. growth of the first human principle and becoming a personality emanating from spiritual culture of humanity. In my definition, I proceed from the assumption that education in its fundamental social mission is a human source of existence and evolution of the whole society. For a person as such, education is one of the places "for possible development of humanity" (Heidegger, 1977b).

Forgetting about human origin in its essence, the education loses it as well as the truth of itself in reality. It serves politics, economics, interests of doctrinal groups, social passions and predilections. It forgets about a learner, a teacher (a professor), a pedagogical team, parent's hopes, human values, 
present and future of the society that it grows, i.e. about social and existential essences and truths of educational being.

The ontological essence of education gives an approach to understanding its social and existential essences, reflecting a dual nature of a person. The social essence of education is expressed in its action as a system of cognitive initiation into society, which gives an individual an overall "picture" of the world, a social reflex, instrumental knowledge, included in the life praxis. The existential essence of education consists in cognitive becoming of a person as such - something internal, when a person comprehends what means to be someone for oneself and someone in the world, i.e., in the space of own realization and, first of all, spiritual, and then cultural, social, professional, etc. The social essence of education leads a person to the surface of existence, but the existential essence directs into depths of being.

Here, relations of education with buman truth are complex. The social essence of education initiates programming of a person, thereby diverting from the truth. However, evils of life revert thinking to a purpose of life, surmount of attitudes, search for the truth. Thereby, the unsettledness of life directs to self-understanding, and thus to selfidentification, which is the matter of the existential essence of education. The existential essence of education, by problematizing an individuality, leads "up hill and down dale" of being, guiding to fantasies, dreams, fictions, figments, phantoms of thoughts. Its intention to depth of being does not guarantee discovery of the truth, but raises a question of equipment status of thinking undertaking this dangerous journey, including the contextual equipment that is the matter of the social essence of education.

Education in Russia has a huge shortage in humanity, and therefore, in truth. The state in which it resides rejects the development of human qualities which are adequate to cultural demands of the time. First of all, this is applicable to productive thinking and creativity - the fundamental factor of social success, the basis of spiritual growth, and the instrument of knowledge production. In the global cultural context, human creativity today gives rise to the very capacity of a person for existence, determines a potential for social and economic growth. Thus, education, eliminating thinking and creativity, transforms a deficit of the future in its realization into unenviable fate of a man and society.

According to the Global Competitiveness Index (GCI, 2017-2018), Russia ranks 64 for quality of the educational system, 51 for quality of mathematics and natural science education, 59 for talent retention. Ahead of Russia are Qatar (5, 6, 9 places), India (26, 37, 24 places), Mauritius (49, 35, 
49 places) (WEF, 2017). In 2017, financing of Russian higher education was approx. $0.56 \%$ of GDP (in 2013, it was $0.7 \%$ ), while in OECD countries, it was $0.9 \%$ of GDP. Emigration of highly qualified specialists within three years is doubled - in 2016, 44 thousand scientists left the country, in 2013 20 thousand.

A consequence of social deprivation of human creativity was a failure in innovative development of the country. Over the total measurement period of the Global Innovation Index (GII) from 2007 to 2017, Russia climbed only nine positions - from 54 to 45, i.e. a growth is practically absent; and in the last year, there was a decrease. On the global map of start-ups (www.startupblink.ro) in June 2018, only 901 startups were registered in Russia in comparison with 31883 in the USA.

The politically implanted existential deprivation of education led to a deficit in culture of the past and present in its existence. So, the Russian school is aimed at cultivation of authoritarian practices of obedience, eliminating the essence of a present-day personality. They are based on intellectual drilling, standardization of cognition, unquestionable obedience and control, which exclude essential thinking, critical interpretation of oneself, the world and oneself in the world, ability to act independently, to risks and their assessment, a constructive initiative (that underpins innovations), self-assertion. Such education substitutes thinking for interpreting, forms uniformity of pandering and pleasing citizens, utilizes a person for needs of domination and thereby belittles a person as a human being.

The process of the existential decline of the school takes place against the background of cultural deprivation of the society as a whole, is connected with it and guided by it. In Russia, games and shows replace reality, while only one bookstore per 50-55 thousand people is available. This is ten times less than in today's Europe, three times less than in Soviet Russia (1989), half as many as in the Russian Empire (1898). Only 10\% of young Russians at the ages from 15 to 24 read books.

Thereby, education in Russia is rapidly losing its ontological essence, becoming "education-beyond-truth" or, in other words, non-education, the thing the society can't deem as education or think about it in those social, cultural and epistemic forms that are intrinsic to education as such.

\subsection{Educational universals in relation to truth}

The role of primary learning constituents of the education phenomenon in the system of its ontological principles is played by educational universals. 
The educational universals are primary elements of a learning action, having a timeless character and generating its unchanging essence, i.e. the field of learning identity in implementation of the education phenomenon. They possess categorically ambivalent character by embodying primary forms and primary contents. They constitute a stable core of a learning action not dependent on epochs and peoples, and set a fundamental possibility of education as such. Educational universals can be interpreted as eidos of the education phenomenon, its initial substances that contain fundamental determinations of the education nature in their genetic code. Transformation of the education in presence, deforming the sphere of responsibility of universals, takes it beyond the limits of true existence.

I distinguish structural, procedural, psychic and distributive universals.

Structural universals determine translational, group and temporal learning structures. In such a way, they characterize a formula of pedagogical interaction "from one leader to many followers", a presence and a structure of groups in the educational community (learner's and teacher's collectives, supporting personnel), parameters of groups of learners, and duration of studies.

Procedural universals regulate forms, an order and norms of the learning action, in particular, they set types and tools of education processes organization for different age groups and its sequence; stipulate a subjection of the educational discourse to special requirements for form, structure, content, subject relations; constitute norms of a closed nature of the educational space.

Psychic universals are associated with conscious and unconscious contents in organization of learning and its processes. They define that learning is based on rational and non-rational acts of knowledge "transfer", takes place in conditions of mutual projections, and conditioned by archetypes. They lay down principles of interaction, roles and disciplinary practices in learner's and teacher's collectives, mechanisms for motivations support, etc.

Distributive universals determine social and educational interaction of knowledge and cognition and, in particular, specify processes of knowledge transfer from creators through translators to learners, regulate ownership of knowledge, a measure of its freedom, mechanisms for its socialization, limitation and control.

Deformation of universals in present-day Russian education shifts it beyond the limits of true existence.

As a result of a merger policy, schools have transformed into bureaucratic organizations. If earlier a director knew own pupils and 
teachers, and they, in turn, knew almost all in their community, now the "learner and pedagogical collectives" notion is buried in memories of the past (structural universals). An increasing teacher's burden under the guise of rise in salaries gives no time for free communication with schoolchildren, i.e. the key instrument of child guidance and pedagogical support for personality unfolding (procedural and psychic universals). A teacher has no time for own spiritual and professional growth. From a mentor to schoolchildren, a teacher turned into a "TV presenter", absent outside the "program schedule"; and the school transformed from a place of study to a place of visit (distributive universals).

Testing at the school as a total checkout aid has modified the learning process into a "crossword" form of training, substituting cognition by mnemonics, knowledge - by information, a lesson - by recitation, a teacher by a checker, a class - by disunity, pedagogical care by disciplinary supervision. In so doing, the very core of the overall system of educational universals has been deconstructed.

For instance, let's take a closer look at what has happened as a result of substituting knowledge for information that has deformed psychic universals. Education creates a person by means of knowledge, who cultivates it in oneself. Knowledge is an inner product of a subject, which Plato called recalling. Knowledge is the effect of the internal on the external, while information is the effect of the external on the internal. Substitution of knowledge for information makes it impossible to read the text with thorough understanding. Information forms the sophomoric, not meaningful understanding, and has a status of temporary acquisition (Karpov, 2017). The latter is, by no means, necessary for future life or for internal growth of an individual, i.e. is beyond social and existential essences of education.

"Measuring materials" not only failed to fix "quality" of the spiritual world, trueness of the civic stance, ability to human understanding and comprehension, they formed "clip-like" thinking, programmed worldviews, utilitarian-pragmatic apperception. All these facts, supplemented by police measures in exams (in practice, examination has transformed into a police operation with its specific procedures of perquisition, shadowing, convoying and monitoring of communication channels), gave the Russian school the essence of a penitentiary institution.

As a result of deformation of educational universals, the Russian school has become a dissensus community functioning in the spirit of American educational culture at the beginning of the last century. For example, Cubberley (1916) in "Public School Administration", published in 1916 in Boston, speaks about the school as a factory, "in which the raw 
products (children) are to be shaped and fashioned into products to meet the various demands of life".

\subsection{Paradigm of education in relation to the truth}

Fundamental paradigmatic relations are included in the system of ontological principles of the education phenomenon. They determine its ability to be a cultural and historical what is and become clear through a question posed to its being. This question can be addressed to forms, ways, functions and generalization of being of the education phenomenon.

The forms of being in which the education phenomenon is actualized are specified by institutionalization and learning environment. The ways of being, through which the education phenomenon exhibits itself, are expressed in organization of working with knowledge and, in particular, learning. Unlike the forms and ways of being, which are aimed at the very existence of the education phenomenon, its function of being is focused on objects external to it; it includes types of cognitive actions. The ontological characteristic of the function of being of education is a dominant quality of a cognitive method (the epistemic dominant). The generalization of being of the education phenomenon in this or that realization is manifested as an imperative, i.e. as a key regulator of relationships of being that combine the form, the way and the function of being.

The paradigm of education phenomenon - implicit or local, is defined by me as a model having a generating system of fundamental concepts-descriptors that represent forms, ways, functions and generalization of its being (Karpov, 2013). This non-Kuhn's definition of the paradigm of the sociocultural phenomenon is developed in connection with performativity, which fundamentally distinguishes it from the naturalscientific phenomenon, which was the subject of Kuhn's conceptualization.

Paradigms of education cultivated by the society give a clue about what it deserves. Among them, paradigms of education development play a special role and predetermine the future of society as a whole. By elimination the paradigm of education development, society deprives of its future and stagnates in the regressive present. In this society, the implicit paradigm of education becomes rigid to the culturally necessary. It produces a space of socio-economic insufficiency that destroys the society, and a sphere of existential deficiency that hinders internal unfolding of a person. As a result, by deforming the social and existential essence of education, it forms the "education-beyond-truth".

The leading paradigm of higher education development is determined today by the University 3.0 concept, which, carries out a mission 
of socio-economic development along with classical missions of learning and research (Lane, 2013). The form of its being is cluster-network types of institutionalization and innovative ecosystems. The ways of being are hybrid methods of working with knowledge, combining learning, creation and social incorporation of knowledge; and, what is more, learning represents a complex form of synthesis between disciplinary, research and scientificentrepreneurial training. The function of being is cognizing productive thinking on the basis of human creativity. The imperative is a growth of social welfare.

The University 3.0 model takes its origin in the second half of the twentieth century - in years of modernization of national economies and emergence of mass higher education, which is formed in the USA and the USSR by the 1960s and 20 years later in most of Europe, including Britain, France, Germany (Trow, 1968). Here lies a deep cultural and economic break with the past. For example, back in the early 1940s, even top managers in large US companies rarely had a university diploma; IBM hired its first manager with higher education a year or two before the Second World War (Drucker, 2008). In 1958, the share of labor in the American knowledge industry with account its potential student share, was 42.8\%, and by 1970 it reached 53.1\% (Machlup \& Kronwinkler, 1975).

That period, the higher education in the USSR was stuck in industrial culture of the first half of the twentieth century. The University worked as a provider of professional personnel, and their training tool was adaptive learning (which is alive today). Such learning is rigid to development of creative thinking - the basis of present-day professions. It is very similar to what P. Freire (1985) called in 1921 as "nutritionist concept of education", where learning cognition is organized as passive and "nutritive" perception.

University 3.0 not only changes a personality, but also globally changes the society. The University of Cambridge has transformed Cambridgeshire into an innovative cluster. The central role in its mission is played by Cambridge Enterprise, founded in 2006 to "help students and employees in commercialization of their knowledge and ideas". In five years, the university ecosystem gave birth to 11 companies with total capitalization of 1.3 billion pounds (University of Cambridge, 2016). The MIT innovation initiative (2016), among its strategic plans, specifies the support to innovative ecosystems around the world, the creation and expansion of global innovation communities unifying innovators, entrepreneurs, corporations and politicians in solving common global problems (MIT, 2016). 
It should be noted that the University 3.0 model should not be regarded as quantitatively dominating in the system of modern education. For example, twenty years later from the day of Bayh-Dole Act, the number of US universities taking part in technology transfer is about two hundred (Thursby \& Kemp, 2002). University 1.0, dealing only with education and University 2.0 - with training and research and their various modifications also occupy their places in the system of modern education.

In Russian education, University 3.0 is, in reality, the excluded paradigm of education development. According to data of monitoring (2016), total income of 40 elite Russian universities from the use of intellectual property in 2015 was only 15.6 million rubles. (approx. 260 thousand dollars); on average, any intellectual property object accounted for 1450 rubles (\$24) in income. Under the international patenting procedure, only 32 patents were received out of all patents in hands (i.e. $0.3 \%$ ). For comparison: in 1989-1990, US universities received \$ 82 million revenue from licensing, and in 2009 - more than \$ 1.5 billion. In 2015 year, the University of Leuven held in its patent portfolio 586 active patent families, i.e. groups of patents issued in different countries for the same invention.

For the period from 2009 to 2015 or seven years, the number of small innovative enterprises founded by 24 out of 40 elite Russian universities was less than ten; in two universities they were absent ("Monitoring of efficiency", 2016). Meanwhile, in 2003-2004, 53 companies were detached from the Imperial College of London, 48 - from the University of Manchester, 45 - from the University of Oxford. During that period, more than 150 new companies were founded every year around MIT (Wissema, 2009).

The consequence of elimination the paradigm of University 3.0 development in Russia is a stagnation and regress in implementation of classical missions - learning and research, which are traditionally valued by global ratings (Marhl \& Pausits, 2011).

Within five years of Project 5-100 implementation, none of its participants entered Top 100 world ratings of THE, QS, ARWU, although minimum five were planned. In spite of the fact that more than one billion dollars of budget were invested in University 21, all universities fall outside of the second hundred.

\section{Conclusions}

Education as a social phenomenon is capable of being itself only when observing ontological fundamentals, which retain the truth of 
educational being. The ontological basis predetermines the presence of the social and existential necessary in education, and its deficit makes problematic the ability of education to be itself. The structure of the ontological basis sets up a categorical schematic for analyzing the education phenomenon and, thereby, specifies a methodology for ontological research that paves the way for definition the truth in its existence.

Deformation of the ontological basis destroys education in "here and now" reality. The prospect for this kind of essential consequences is elimination the beingness possibility for education in presence which allows it to be education. Deconstruction of education as a phenomenon of existence is the result of this fact. It becomes unable to reproduce a person and society in the very essence in which they abide; changes into education of frustrated expectations, a bootless effort having no unconditional and indisputable, existential and social values.

\section{References}

Aoki, T. (2004). Curriculum in a new key: The collected works of Ted Aoki (Studies in curriculum theory series). New York, USA: Routledge.

Cubberley, E. P. (1916). Public school administration: A statement of the fundamental principles underlying of the organization and administration of public education. Boston, USA: Houghton Mifflin.

Dall'Alba, G. (2009). Learning professional ways of being: Ambiguities of becoming. In G. Dall'Alba (Ed.), Exploring Education Through Phenomenology: Diverse Approaches (pp. 41-52). Oxford, UK: Weley-Blackwell Publishing.

Doll, W. E. (1993). A post-modern perspective on curriculum. New York, USA: Teacher College Press.

Drucker, P. F. (2008). Concept of the corporation. London, UK: Transaction Publishers.

Freire, P. (1985). The politics of education. Culture, power and liberation. Westport, USA: Bergin \& Garvey Publishers Inc.

Heidegger, M. (1977a). Science and reflection. In M. Heidegger, The question concerning technology and other essays (pp. 155-182). New York, USA: Harper Torchbooks.

Heidegger, M. (1977b).The Age of the world picture. In M. Heidegger, The question concerning technology, and other essays (pp. 115-154). New York, USA: Harper Torchbooks.

Heidegger, M. (1998). Plato's doctrine of truth. In M. Heidegger, Pathmarks (pp. 155-182). Cambridge, UK: Cambridge University Press. 
Karpov, A. O. (2018). Fundamentals of education in knowledge society: Theoretical forecast. Revista Romaneasca pentru Educatie Multidimensionala, 10(1), 171-182. doi:10.18662/rrem/27

Karpov, A. O. (2015). Social'naya i ehkzistencial'naya ontologizacii obrazovaniya [The social and existencial ontologization of education]. Voprosy Filosofii, 1, 3-13.

Karpov, A. O. (2013). Social'nye paradigmy i paradigmal'no-differencirovannaya sistema obrazovaniya [Social paradigms and paradigmatic differentiated system of education]. Voprosy Filosofii, 3, 22-32.

Karpov, A. O. (2017). The problem of separating the notions of "knowledge" and "information" in the knowledge society and its education. Procedia - Social and Behavioral Sciences, 237, 804-810. doi:10.1016/j.sbspro.2017.02.152

Lane, J. E. (2013). Higher education system 3.0: Adding value to states and institutions. In J. E. Lane \& B. Johnstone, Higher education system 3.0: Harnessing systemness, delivering performance (pp. 3-26). New York, USA: State University of New York Press.

Machlup, F., \& Kronwinkler, T. (1975). Workers who produce knowledge: A steady increase, 1900 to 1970. Review of Works Economics, 111(4), 752-759. doi:10.1007/bf02696490

Magrini, J. M. (2012). An ontological notion of learning inspired by the philosophy of hannah arendt. Philosophy Scholarship, Paper 34. Retrieved from http://dc.cod.edu/philosophypub/34

Magrini, J. M. (2014). A «fundamental theory» of education grounded in ontology? A phenomenological rejoinder. Reconstruction, 14: Phenomenology and Education, 2, 17-44.

Marhl, M., \& Pausits, A. (2011). Third mission indicators for new ranking methodologies. Evaluation in Higher Education, 5, 43-64. doi:10.15393/j5.art.2013.1949

Massachusetts Institute of Technology (MIT). (2016). MIT Innovation Initiative: Final report of community feedback and recommendations. Cambridge, UK: Massachusetts Institute of Technology.

Monitoring ehffektivnosti innovacionnoj deyatel'nosti universitetov Rossii [Monitoring of efficiency of innovative activity of universities in Russia]. (2016). St. Petersburg, Russia: Universitet ITMO, AO «RVK». 
Pinar, W. F. (2012). The reconceptualization of curriculum studies. In D. J. Flinders \& S. Thornton (Eds.), The curriculum studies reader (pp. 149-156). New York, USA: Routledge.

Poli, R. (2010). Ontology: The categorial stance. In R. Poli \& J. Seibt (Eds.), Theory and applications of ontology: Philosophical perspectives (pp. 1-22). New York, USA: Springer.

Schatzki, T. R. (2003). A new societist social ontology. Philosophy of the Social Sciences, 33(2), 174-202. doi:10.1177/0048393103033002002

Schubert, W. H. (1991). Philosophical inquiry: The speculative essay. In E. C. Short (Ed.), Forms of Curriculum Inquiry (pp. 61-76). Albany, USA: SUNY Press.

World Economic Forum (WEF). (2017). The Global Competitiveness Report 2017-2018. Retrieved from https://www.weforum.org/reports/the-globalcompetitiveness-report-2017-2018

Thomson, I. (2004). Heidegger's perfectionist philosophy of education in Being and Time. Continental Philosophy Review, 37(4), 439-467. doi:10.1007/s11007-0056886-8

Thursby, J., \& Kemp, S. (2002). Growth and productive efficiency in university intellectual property licensing. Research Policy, 31(1), 109124. doi:10.1016/s0048-7333(00)00160-8

Trow, M. (1968). The sociology of education. In T. Parsons \& Voice of America (Eds.), American sociology: Perspectives, problems, methods (pp. 131-142). New York, USA: Basic Books.

University of Cambridge. (2016). University of Cambridge Enterprise: Annual Review. Cambridge, UK: Cambridge Enterprise Limited.

Wissema, J. G. (2009). Towards the third generation university: Managing the university in transition. Cheltenham, USA: Edward Elgard Publishing. 